\title{
PENGARUH KEPEMIMPINAN TRANSFORMASIONAL DAN PEMBERDAYAAN TERHADAP KEPUASAN KERJA PEGAWAI BIRO UMUM DAN PROTOKOL SETDA PROVINSI BALI
}

\author{
Putu Sudibyadnyana ${ }^{1}$ \\ Desak Ketut Sintaasih ${ }^{2}$ \\ ${ }^{1,2}$ Fakultas Ekonomi dan Bisnis Universitas Udayana (Unud), Bali, Indonesia \\ e-mail: putusudibyadnyana@gmail.com
}

\begin{abstract}
ABSTRAK
Sumber daya manusisa merupakan sumber daya yang penting untuk keefektifan organisasi. Tujuan penelitian ini adalah untuk menjelaskan pengaruh kepemimpinan transformasional dan pemberdayaan Pegawai terhadap kepuasan kerja. Penelitian ini dilakukan pada Biro Umum dan Protokol Setda Provinsi Bali, dengan sampel sebanyak 86 orang pegawai. Teknik analisis yang digunakan adalah analisis regresi linier berganda. Hasil penelitian menunjukkan bahwa kepemimpinan transformasional berpengaruh positif terhadap kepuasan kerja dan pemberdayaan pegawai berpengaruh positif terhadap kepuasan kerja. Saran yang dapat diberikan dalam penelitian ini yaitu pihak instansi sebaiknya menciptakan hubungan kerja yang positif baik antara atasan dengan pegawai maupun antara sesama pegawai. Agar kepemimpinan transformasional dapat terwujud dan kepuasan kerja dapat ditingkatkan, sebaiknya pimpinan membuat situasi dalam organisasi jadi terasa senyaman mungkin agar pegawai merasa nyaman bekerja dan membuat pegawai merasa menjadi bagian keluarga organisasi tersebut. Rasa kekeluargaan yang tercipta akan membuat pegawai lebih baik dalam bekerja dan memberikan hasil yang bagus dalam bekerja.
\end{abstract}

Kata kunci : kepemimpinan transformasional, pemberdayaan pegawai, kepuasan kerja

\begin{abstract}
Human resources are an important resource for organizational effectiveness. The purpose of this study is to explain the influence of transformational leadership and empowerment of employees to job satisfaction. This research was conducted at the General Bureau and Protocol of Regional Secretariat of Bali, with sample of 86 employees. The analysis technique used is multiple linear regression analysis. The results showed that transformational leadership has a positive effect on job satisfaction and employee empowerment have a positive effect on job satisfaction. Suggestions that can be given in this research that the agency should create a positive working relationship both between employers with employees and between fellow employees. In order for transformational leadership to be realized and job satisfaction can be improved, the leader should make the situation in the organization so feels as comfortable as possible so that employees feel comfortable working and make employees feel part of the family of the organization. The sense of kinship created will make employees better at work and provide good results in work
\end{abstract}

Keywords: transformational leadership, employee empowerment, job satisfaction 


\section{PENDAHULUAN}

Organisasi merupakan sistem sosial dimana sumber daya manusia sebagai faktor utama untuk mendapatkan keunggulan kompetitif dan mempengaruhi keefektifan organisasi. Tanpa adanya sumber daya manusia, organisasi tidak bisa berjalan dengan baik sesuai dengan apa yang diinginkan. Organisasi memerlukan kerja sama antara pimpinan dan pegawai untuk meraih tujuan organisasi yang telah ditetapkan. Studi mengenai kepuasan kerja sangat penting diakukan karena memiliki pengaruh yang signifikan terhadap sikap pegawai dan sikap kerja secara langsung. Kepuasan kerja berfungsi untuk memahami tujuan dari organisasi.

Kepuasan kerja merupakan sesuatu yang bersifat individual dan setiap individu memiliki tingkat kepuasan berbeda sesuai sistem nilai yang berlaku pada dirinya (Rivai dan Sagala, 2011:856). Hal yang serupa juga dinyatakan oleh Mathis dan Jackson (2011:121) bahwa kepuasan kerja adalah keadaan emosional yang positif yang merupakan hasil dari evaluasi pengalaman kerja seseorang. Kepuasan kerja sulit didefinisikan karena rasa puas itu bukan keadaan yang tetap melainkan dapat dipengaruhi dan diubah oleh kekuatan-kekuatan baik dari dalam maupun dari luar lingkungan kerja (Suwatno dan Priansa, 2011). Sutrisno (2014:75) menyatakan ketidakpuasan karyawan dalam kerja akan mengakibatkan suatu yang tidak menguntungkan baik secara organisasi maupun individual. Ketidakpuasan karyawan akan dapat menimbulkan perilaku yang menunjukkan sikap menarik diri dari organisasi, misalnya dengan mengambil sikap berhenti dari organisasi, tidak semangat bekerja, jarang masuk kantor dan perilaku lain yang cenderung bersifat menghindari dari aktivitas organisasi. 
I Putu Sudibyadnyana, Pengaruh Kepemimpinan Transformasional dan...

Karyawan yang merasa puas akan menghasilkan kerja yang baik sehingga mempercepat tercapainya tujuan dari organisasi. Kepuasan kerja yang tinggi berdampak pada kehadiran dan ketekunan karyawan saat bekerja, maka karyawan memiliki prestasi kerja dan kinerja yang baik. Uraian tersebut dinyatakan bahwa kepuasan kerja karyawan merupakan masalah penting yang perlu diperhatikan dalam hubungannya dengan produktivitas kerja karyawan (Sutrisno, 2014:77). Irsan (2008) menyatakan bahwa kepuasan kerja dipengaruhi oleh banyak variabel, seperti struktur organisasi, karakteristik karyawan, motivasi kerja, disain pekerjaan, iklim organisasi, perilaku pemimpin atau kepemimpinan.

Salder dalam Wuradji (2008:48) menyebutkan bahwa gaya kepemimpinan transformasional adalah suatu proses kepemimpinan dimana pemimpin mengembangkan komitmen pengikutnya dengan berbagai nilai-nilai dan berbagai visi organisasi. Kepemimpinan sering disebut sebagai orang yang kuat dan dinamis yang dapat mempengaruhi manajemen organisasi (Ismail dkk., 2011). Kepemimpinan sangat dibutuhkan untuk memotivasi bawahan dalam rangka pencapaian tujuan bersama (Maharani dkk., 2013). Kepemimpinan Transformasional telah menjadi perhatian dari banyak peneliti saat ini untuk membantu kesuksesan organisasi. Lebih lanjut Krishnan (2005) menjelaskan kepemimpinan tranformasional dapat menciptakan value system diantara pemimpin dan pengikut dimana mereka saling memotivasi untuk meraih tujuan organisasi. Dohert dan Danylchuk (1996) menjelaskan kepemimpinan transformasional memiliki pengaruh yang signifikan untuk membantu meningkatkan kepuasan kerja karyawan. 
Variabel lain yang mempengaruhi kepuasan kerja adalah pemberdayaan pegawai. Lin et al., (2013) menunjukkan bahwa perilaku kepemimpinan dan pemberdayaan menjadi suatu hal yang penting dan berdampak positif bagi kepuasan kerja karyawan. Pemberdayaan karyawan adalah proses memberikan karyawan kemampuan dan wewenang sehingga memudahkan karyawan untuk mengambil tindakan pribadi, berkarya dan perilaku yang memberikan kontribusi positif bagi misi organisasi (Nongkeng et al., 2011). Pemberdayaan dapat meningkatkan komitmen kerja karyawan dan menghilhami perubahan yang membantu tujuan organisasi (Sahoo, 2011). Appelbaum et al. dalam Khuzani (2008) mengatakan bahwa karyawan yang diberdayakan memiliki empat karakteristik umum yakni, mempunyai rasa Self-determination, rasa Meaning, rasa competence, dan rasa impact.

Penelitian ini dilaksanakan di Biro Umum dan Protokol Setda Provinsi Bali. Kondisi Kepemimpinan pada Biro Umum dan Protokol Provinsi Bali belum mampu memecahkan permasalahan yang ada, hal ini dikarekanan pemimpin dalam mengayomi bawahannnya banyak mendapatkan kendala-kendala dalam hal komunikasi. Pegawai yang mencoba menginformasikan permasalahan kerja yang dihadapi kurang mendapat respon dari pemimpinnya. Komunikasi yang disampaikan sering terjadi dengan satu arah, yaitu secara vertikal dari atasan kepada bawahan yang berupa perintah atau instruksi yang harus dijalankan oleh pegawai, sedangkan komunikasi dari bawahan kepada atasan atau pimpinan seperti usulan untuk perbaikan kinerja instansi tidak pernah ditanggapi secara serius oleh pimpinan. Hal ini ditunjukkan dengan tidak adanya monitoring untuk 
I Putu Sudibyadnyana, Pengaruh Kepemimpinan Transformasional dan...

pegawai tugas luar dan pegawai mengisi waktu kerja mereka dengan melakukan kegiatan-kegiatan yang kurang bermanfaat bagi organisasi pada jam-jam kerja, seperti membaca koran, memainkan ponsel pasa saat jam kerja. Hal ini sangat jelas merugikan organisasi. Mengantisipasi permasalahan kepemimpinan tersebut, maka Biro Umum dan Protokol Setda Provinsi Bali melakukan perubahan penerapan kepemimpinan baru yaitu gaya kepemimpinan transformasional. Permasalahan juga ditemukan pada pemberdayaan, yaitu kurang percayanya atasan dengan bawahan, hal ini dapat dilihat dari pemberian tanggung jawab hanya pada satu pegawai saja dan tidak memberikan kesempatan yang cukup besar untuk terlibat dalam pekerjaan kepada pegawai lainnya, contohnya adalah pada Biro Umum dan Protokol Setda Provinsi Bali pegawai tidak diberikan kesempatan secara adil untuk melakukan pekerjaan yang lainnya, seringkali atasan tidak bersikap adil untuk menunjuk pegawai dalam melalukan pekerjaan, karena salah satu pekerjaan tersebut mendapatkan insentif, salah satunya adalah tugas keluar daerah untuk mengikuti rapat-rapat dan pendidikan pelatihan, hal tersebutlah yang menyebabkan permasalahan pada pemberdayaan.

Permasalahan-permasalahan tersebut, diatas dikhawatirkan akan dapat mengurangi mengganggu organisasi dalam menjalankan aktivitasnya, sehingga hal ini cukup relevan diadakan penelitian dengan judul : "Pengaruh Kepemimpinan Transformasional dan Pemberdayaan terhadap Kepuasan Kerja Pegawai Biro Umum dan Protokol Setda Provinsi Bali.”

Berdasarkan latar belakang masalah di atas, maka dapat dirumuskan masalah dalam penelitian yaitu, Bagaimana pengaruh kepemimpinan 
transformasional terhadap kepuasan kerja Pada Biro Umun dan Protokol Setda Provinsi Bali. Bagaimana pengaruh pemberdayaan pegawai terhadap kepuasan kerja Pada Biro Umun dan Protokol Setda Provinsi Bali. Berdasarkan dengan latar belakang dan rumusan masalah, maka tujuan penelitian ini yaitu, Untuk mengetahui pengaruh kepemimpinan transformasional terhadap kepuasan kerja Pada Biro Umun dan Protokol Setda Provinsi Bali. Untuk mengetahui pengaruh pemberdayaan pegawai terhadap kepuasan kerja Pada Biro Umun dan Protokol Setda Provinsi Bali.

Kusmaningtyas (2013) menyatakan kepuasan kerja merupakan suatu refleksi terhadap terpenuhinya kebutuhan dan keinginan individu yang didapat dari pekerjaannya. Sementara Siagian (2011:295) mendefinisikan bahwa kepuasan kerja merupakan cara pandang seseorang baik yang bersifat positif maupun negatif tentang pekerjaannya. Kepuasan kerja dapat digambarkan sebagai suatu perasaan atau keadaan pikiran mengenai sifat pekerjaan (Adeniji, 2011). Handoko (2014:193) menyatakan kepuasan kerja adalah keadaan emosional yang menyenangkan atau tidak menyenangkan dengan para karyawan memandang pekerjaan mereka. Hasibuan (2007 : 202) menyatakan bahwa kepuasan kerja merupakan sikap emosional yang menyenangkan dan mencintai pekerjaannya. Sikap ini dicerminkan oleh moral kerja, kedisiplinan, dan prestasi kerja. Gorda dalam Dhermawan, dkk (2012) berpendapat bahwa kepuasan kerja adalah faktor pendorong meningkatnya kinerja karyawan yang pada gilirannya akan memberikan kontribusi kepada peningkatan kinerja organisasi. 
I Putu Sudibyadnyana, Pengaruh Kepemimpinan Transformasional dan...

Pemaparan definisi diatas dapat dikemukakan bahwa kepuasan kerja adalah tentang perasaan senang sampai tidak senang yang dirasakan pegawai terhadap berbagai aspek pekerjaannya. Jika seorang pegawai mendapatkan kepuasan kerja yang tinggi maka pegawai tersebut akan menunjukkan produktivitas kerja yang baik, sebaliknya pegawai yang mendapatkan kepuasan kerja yang rendah maka pegawai tersebut akan menunjukkan produktivitas yang tidak baik pada organisasi. Menurut Hasibuan (2014:203) faktor-faktor yang mempengaruhi kepuasan kerja karyawan antara lain balas jasa yang adil dan layak, penempatan yang sesuai dengan keahlian, berat ringannya pekerjaan, lingkungan pekerjaan, peralatan yang menunjang pelaksanaan pekerjaan, sikap pimpinan dalam memberdayakan karyawan, dan sifat pekerjaan yang monoton atau tidak.

Menurut Kreitner dan Kinicki dalam Wibowo (2013:225) disebutkan bahwa, faktor-faktor yang memiliki hubungan dengan kepuasan kerja karyawan diantaranya Motivasi, kepemimpinan transformasional, pelibatan kerja, organizational citizenship behavior (OCB), perputaran karyawan, stress kerja, prestasi kerja, komitmen organisasional, dan kepuasan hidup.

Maulizar (2012) menyatakan bahwa pemimpin transformasional adalah pemimpin yang memotivasi bawahannya untuk bekerja demi mencapai sasaran organisasi dan memuaskan kebutuhan mereka pada tingkat yang lebih tinggi. Hughes et al. (2012:542) mengemukakan bahwa pemimpin transformasional memiliki visi, keahlian retorika, dan pengelolaan kesan yang baik dan menggunakannya untuk mengembangkan ikatan emisional yang kuatdengan 
karyawannya, sehingga mendorong tergugahnya emosi karyawan serta kesediaan mereka untuk bekerja mewujudkan visi sang pemimpin.

Pemberdayaan adalah salah satu dari berbagai cara untuk mengembangkan pegawai melalui pelatihan, wewenang dan tanggung jawab dalam keputusan untuk menyelesaikan tugas. Pemberdayaan merupakan sebuah kekuatan yang sangat diperlukan disuatu perusahaan untuk meningkatkan semangat pegawai dalam melayani masyarakat. Adanya pemberdayaan pegawai diharapkan dapat memotivasi pegawai untuk meningkatkan semangat yang lebih tinggi. Pemberdayaan merupakan suatu proses untuk menjadikan orang menjadi lebih berdaya atau lebih berkemampuan untuk menyelesaiakan masalahnya sendiri, dengan cara memberikan kepercayaan dan wewenang sehingga menumbuhkan rasa tanggung jawab (Kadarisma, 2012:415). Menurut Akbar et al. (2011), pemberdayaan karyawan didefinisikan sebagai pemberi dorongan untuk karyawan membuat keputusan. Pemberdayaan karyawan merupakan salah satu cara mendorong karyawan untuk lebih terlibat dalam pembuatan keputusan dan bertanggung jawab terhadap pekerjaan dan organisasi (Wibowo, 2011:416).

Hubungan antara Pemberdayaan karyawan dan kepuasan kerja sangat erat dimana pemberdayaan karyawan adalah memberikan dan melepaskan kekuasaan dengan memberikan karyawan kebebasan, sumber daya, informasi dan keterampilan untuk membuat keputusan dalam menyelesaikan pekerjaan secara efektif, tepat waktu dan mendorong karyawan agar lebih berpartsipasi dan memberikan rasa puas terhadap karyawannya (Deft, 2009:79). 
I Putu Sudibyadnyana, Pengaruh Kepemimpinan Transformasional dan...

Berdasarkan uraian tersebut dapat dikemukakan bahwa pemberdayaan pegawai merupakan upaya dari atasan terhadap bawahan untuk menjadikan pegawai lebih berdaya dengan cara memberikan wewenang dan kepercayaan dalam hal menjalankan pekerjaan maupun mengambil keputusan, sehingga akan menumbuhkan rasa tanggung jawab pada pegawai dalam menjalankan pekerjaan. Menurut Gasperz dalam Kadarisman (2013:241) manfaat dari pemberdayaan karyawan ialah, pekerjaan mereka (karyawan) merupakan milik mereka, mereka bertanggung jawab, mereka mengetahui dimana mereka berada dan mereka memiliki beberapa kendali atas pekerjaan mereka.

Berdasarkan definisi dan kajian teori dari beberapa para ahli yang ada, maka dapat disusun suatu kerangka pemikiran sebagai dasar penentu hipotesis seperti

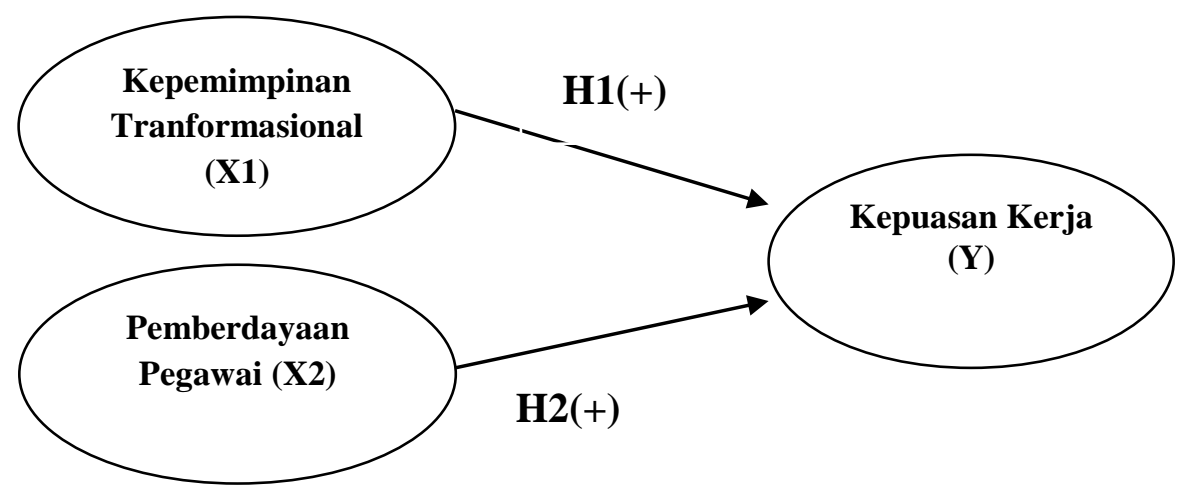

\section{Gambar 1. Model Konseptual Penelitian}

Sumber: Data Diolah, 2017

DuBrin (2005:335) mengatakan kepemimpinan transformasional adalah pemimpin yang membantu organisasi dan orang untuk membuat perubahan positif dalam beraktivitas. Kepemimpinan transformasional, digambarkan sebagai gaya kepemimpinan yang dapat membangkitkan motivasi karyawan, sehingga dapat berkembang dan mencapai kinerja pada tingkat yang tinggi, melebihi dari apa 
yang mereka perkirakan sebelumnya (Sonni, 2013). Terdapat beberapa penelitian mengenai pengaruh kepemimpinan transformasional terhadap kepuasan kerja. Hasil penelitian ini didukung oleh penelitian Yang (2012) bahwa kinerja pengawas dalam hal kepemimpinan transformasional dapat memiliki dampak signifikan positif pada bawahan tingkat kepuasan kerja. Suyuthi, dkk (2009) menunjukkan bahwa kepemimpinan transformasional memberikan tingkat pengaruh terhadap kepuasan kerja yang cukup kuat. Ini mengindikasikan bahwa penerapan kepemimpinan transformasional dapat memberikan kontribusi terhadap peningkatan kepuasan kerja. Omar and Fauzin Hussin (2013) mengatakan bahwa organisasi perlu memiliki pemimpin tipe transformasional untuk memberikan tim yang efektif dalam bekerja untuk meningkatkan kepuasan kerja. Dari penelitian sebelumnya mendasari perumusan hipotesis pertama sebagai berikut.

$\mathrm{H}_{1}$ : Kepemimpinan transformasional berpengaruh positif terhadap kepuasan kerja.

Indradevi (2012) pada penelitiannya menemukan hasil yang positif antara pemberdayaan karyawan terhadap kepuasan kerja, penelitian ini meneliti mengenai dampak pemberdayaan terhadap kepuasan kerja karyawan pada perusahaan perangkat lunak di india. Diperkuat juga dengan Penelitian yang dilakukan oleh Akbar et al. (2011), yang mengukur hubungan antara pemberdayaan karyawan dan kepuasan kerja di industri jasa Pakistan. Hasil penelitian ini menunjukkan pemberdayaan karyawan signifikan dengan kepuasan kerja. Penelitian yang dilakukan oleh Abadi (2013) menunjukkan bahwa pemberdayaan dan dimensi akses ke informasi, sistem penghargaan, penentuan 
I Putu Sudibyadnyana, Pengaruh Kepemimpinan Transformasional dan...

nasib sendiri dan kompetensi berpengaruh signifikan dengan kepuasan kerja. Mushipe (2011) menyatakan bahwa, terdapat hubungan positif antara pemberdayaan terhadap kepuasan kerja karyawan, semakin karyawan itu merasa diberdayakan maka tingkat kepuasan kerjanya meningkat dan begitu pula sebaliknya apabila karyawan kurang merasa diberdayakan maka kepuasan kerjanya akan menurun. Saeed (2013) pada penelitiannya yang menguji hubungan antara pemberdayaan karyawan dan kepuasan kerja juga menemukan hasil bahwa terdapat hubungan positif antara pemberdayaan karyawan terhadap kepuasan kerja. Dari penelitian sebelumnya mendasari perumusan hipotesis kedua sebagai berikut.

$\mathrm{H}_{2}$ : Pemberdayaan Pegawai berpengaruh positif dan signifikan terhadap Kepuasan kerja.

\section{METODE PENELITIAN}

Pendekatan yang akan digunakan untuk meneliti sumber masalah pada penelitian ini adalah pendekatan kuantitatif yang berbentuk asosiatif karena penelitian ini bertujuan untuk mengetahui hubungan antara dua variabel atau lebih. Penelitian ini di laksanakan pada Biro Umun dan Protokol Setda Provinsi Bali yang berlokasi di Jalan Niti Mandala Renon Denpasar Bali. Alasan pertama penelitian ini dilakukan pada Biro Umun dan Protokol Setda Provinsi Bali bahwa belum ada penelitian yang meneliti pengaruh kepemimpinan transformasional dan pemberdayaan pegawai terhadap kepuasan kerja pada Biro Umun dan Protokol Setda Provinsi Bali. Adapun yang menjadi Obyek dalam penelitian ini adalah Kepemimpinan Transformasional, Pemberdayaan Pegawai dan Kepusan Kerja 
pada Biro Umum dan Protokol Setda Provinsi Bali. Berdasarkan pokok masalah dan hipotesis yang diajukan, variabel-variabel dalam penelitian ini dapat diidentifikasi sebagai berikut variabel bebas adalah kepemimpinan transformasional $\left(\mathrm{X}_{1}\right)$ dan pemberdayaan Pegawai $\left(\mathrm{X}_{2}\right)$. variabel terikat adalah kepuasan kerja (Y).

Kepemimpinan transformasional merupakan perilaku pemimpin yang mampu memunculkan rasa bangga dan kepercayaan bawahan, menginspirasi dan memotivasi bawahan, merangsang kreativitas dan inovasi bawahan, memperlakukan setiap bawahan secara individual serta selalu melatih dan memberi pengarahan kepada bawahan. Pemberdayaan merupakan suatu proses untuk menjadikan orang menjadi lebih berdaya atau lebih berkemampuan untuk menyelesaikan masalahnya sendiri, dengan cara memberikan kepercayaan dan wewenang sehingga menumbuhkan rasa tanggung jawab. Kepuasan kerja merupakan suatu refleksi terhadap terpenuhinya kebutuhan dan keinginan individu yang didapat dari pekerjaannya.

Penelitian ini menggunakan dua jenis data yaitu data kuantitatif dan data kualitatif. Data kuantitatif dalam penelitian ini adalah jumlah pegawai dan jawaban responden terhadap kuesioner. Data kualitatif dalam penelitian ini seperti struktur organisasi, aktivitas instansi dan sejarah instansi. Sumber data yang digunakan dalam penelitian ini adalah sumber data primer dan sekunder. Sumber primer yaitu data yang diperoleh secara langsung dari responden penelitian, seperti data yang didapatkan dengan wawancara dan pemberian kuesioner terhadap responden. Sumber sekunder dikumpulkan sebagai pendukung dari data 
I Putu Sudibyadnyana, Pengaruh Kepemimpinan Transformasional dan...

primer yaitu data yang telah dicatat oleh perusahaan seperti jumlah pegawai, tingkat absensi pegawai, struktur organisasi dan sejarah organisasi.

Populasi adalah wilayah generalisasi yang terdiri atas obyek atau subyek yang mempunyai kualitas dan karakteristik tertentu yang ditetapkan oleh peneliti untuk dipelajari dan kemudian ditarik kesimpulannya (Sugiyono, 2014:115). Populasi dalam penelitian ini adalah seluruh pegawai yang bekerja di pada Biro Umun dan Protokol Setda Provinsi Bali yang berjumlah 86 orang. Sampel adalah bagian dari jumlah dan karakteristik yang dimiliki oleh populasi tersebut. Bila populasi besar dan penelitian tidak mungkin mempelajari semua yang ada pada populasi, misalnya karena keterbatasan dana, tenaga dan waktu maka peneliti dapat menggunakan sampel yang diambil dari populasi, untuk itu sampel yang diambil dari populasi harus betul-betul mewakili. Pemilihan sampel dalam penelitian ini menggunakan metode sampel jenuh, dimana sebanyak 86 orang pegawai pada Biro Umun dan Protokol Setda Provinsi Bali dijadikan responden.

Skala pengukuran yang digunakan dalam penelitian ini adalah skala likert. Skala likert merupakan skala yang digunakan untuk mengukur sikap, sifat, pendapat atau persepsi seseorang tentang fenomena sosial (Sugiono, 2012:132). Setiap jawaban kuesioner mempunyai bobot atau skor nilai dengan skala likert

Tabel 1.

Jumlah pegawai pada Biro Umum dan Protokol Bagian - Bagian Jumlah Pegawai (Orang) 
2. Bagian Keuangan Setda

23 Orang

3. Bagian Protokol

13 Orang

4. Bagian Rumah Tangga Pimpinan

19 Orang

$\begin{array}{cr}\text { Total } & 86 \\ \text { Sumber : Tata Usaha Biro Umum dan protokol Setda Provinsi Bali, } 2017\end{array}$

Metode pengumpulan data yang digunakan pada penelitian ini adalah observasi dan wawancara dengan kuesioner sebagai alatnya. Observasi adalah teknik pengumpulan data dengan mengamati objek yang diteliti secara langsung untuk memenuhi data-data yang diperlukan. Dilakukan pengamatan langsung di Biro Umun dan Protokol Setda Provinsi Bali dengan pengamatan langsung dapat mengetahui bagaimana keadaan lingkungan instansi, lokasi instansi, cara kerja pegawai dan masalah yang terdapat di Biro Umun dan Protokol Setda Provinsi Bali. Wawancara yaitu melakukan wawancara langsung kepada pimpinan di Biro Umun dan Protokol Setda Provinsi Bali dan menyiapkan daftar pertanyaanpertanyaan tertulis secara terstruktur yang akan digunakan untuk memperoleh informasi. Kuesioner yaitu memberikan seluruh pegawai atau responden daftar pertanyaan terstruktur yang digunakan untuk memperoleh informasi mengenai penilaian responden terhadap pengaruh pemberdayaan dan kompensasi finansial terhadap kepuasan kerja pada pegawai Biro Umun dan Protokol Setda Provinsi Bali.

Penelitian ini menggunakan kuesioner sebagai alat pengumpul data, sehingga suatu instrumen pada kuisioner dapat diketahui apakah valid dan reliabel dengan cara diuji sebelumnya dengan uji validitas dan reliabilitas. Uji validitas instrumen dilakukan untuk mengukur keandalan dan ketepatan instrumen yang digunakan, instrumen yang valid merupakan instrumen yang benar-benar tepat 
I Putu Sudibyadnyana, Pengaruh Kepemimpinan Transformasional dan...

untuk mengukur apa yang hendak diukur (Sugiyono, 2012:172). Uji reliabilitas merupakan terjemahan dari kata reliability yang berasal dari kata rely dan ability, reliabilitas dapat diartikan sebagai keterpercayaan, keterandalan, atau konsistensi. Hasil suatu pengukuran dapat dipercaya apabila pelaksanaan pengukuran dalam beberapa kali terhadap subjek yang sama diperoleh hasil yang relatif sama. Alat ukur dapat dikatagorikan reliabel apabila mempunyai tingkat reliabilitas yang tinggi. Suatu alat ukur dikatakan reliabel dapat dilihat melalui hasil Reliability Statistic dalam program SPSS. Variabel yang dikatakan reliabel apabila Koefisien Alpha Cronbach = 0,6 artinya tingkat reliabilitas sebesar 0,6 meupakan indikasi reliabelnya sebuah konstruk (Ghozali, 2009:46).Suatu instrument dikatakan reliabel, jika instrument tersebut memiliki nilai Alpha Cronbach lebih dari 0,60.

Penelitian ini menggunakan kuesioner sebagai alat pengumpul data, sehingga suatu instrumen pada kuisioner dapat diketahui apakah valid dan reliabel dengan cara diuji sebelumnya dengan uji validitas dan reliabilitas. Sebelum dilakukan analisis regresi linear berganda terlebih dahulu uji asumsi klasik yaitu uji normalitas, uji multikolinearitas, dan uji heteroskedastisitas. Model analisis yang digunakan untuk menyelesaikan permasalahan penelitian ini adalah regresi linier berganda. Permaslahan yang harus dijawab adalah variabel bebas (kepemimpinan transformasional dan pemberdayaan pegawai) berpengaruh secara simultan, secara parsial, dan dominan terhadap variabel terikat (kepuasan kerja). Analisis selanjutnya digunakan SPSS 15.0. Model regresi linier berganda sebagai berikut (Suyana, 2007:77) : 
$Y=a+\beta_{1} X_{1}+\beta_{2} X_{2}+e \ldots \ldots \ldots$

1)

Keterangan:

$\mathrm{Y}=$ Kepuasan Kerja

$\mathrm{a}=$ Konstanta

$\beta=$ Koefisien regresi

$\mathrm{X}_{1}=$ Kepemimpinan Transformasional

$\mathrm{X}_{2}=$ Pemberdayaan Pegawai

$\mathrm{e}=$ Kesalahan residual (error)

Uji F ini dilakukan untuk menguji apakah secara serempak variabel bebas (Kepemimpinan Transformasional, Pemberdayaan Pegawai) mampu menjelaskan variabel terikat (Kepuasan Kerja) secara baik dan atau untuk menguji apakah model yang digunakan dalam penelitian ini layak untuk digunakan atau tidak. Apabila hasil dari Uji $\mathrm{F}$ menyatakan signifikan $\mathrm{F}$ atau $\mathrm{P}$ value $<0,05$ maka hubungan antar variabel-variabel bebas adalah signifikan mempengaruhi variabel terikat (Ghozali, 2012: 98). Begitupun sebaliknya apabila hasil dari Uji F menyatakan signifikan $\mathrm{F}$ atau $\mathrm{P}$ value > 0,05 maka hubungan antar variabelvariabel bebas adalah tidak signifikan mempengaruhi variabel terikat. Nilai koefisien determinasi menunjukkan kemampuan dari model dalam menjelaskan variasi variabel terikat kepuasan kerja (Y). Koefisien determinasi memiliki nilai dari 0 sampai 1 . Nilai $\mathrm{R}^{2}$ yang rendah memiliki arti dimana kemampuan variabel dalam menjelaskan variabel-variabel bebas memberikan hampir semua informasi yang dibutuhkan untuk memprediksi variabel terikat. Uji t dilakukan untuk mengetahui apakah ada pengaruh yang nyata secara parsial antara variabel bebas (Kepemimpinan transformasional, 
I Putu Sudibyadnyana, Pengaruh Kepemimpinan Transformasional dan...

Pemberdayaan pegawai) dengan variabel terikat (Kepuasan kerja). Dalam menguji pengaruh masing-masing variabel bebas pada penelitian digunakan Uji t, dimana tingkat probabilitas kesalahan $\alpha=5 \%$. Pada pengujian, apabila tingkat signifikansi koefisien beta variabel bebas lebih kecil dari 0,05 maka pengujian signifikan.

\section{HASIL DAN PEMBAHASAN}

Berdasarkan Undang-Undang Nomor 64 Tahun 1958 pada tanggal 14 Agustus 1958, Pemerintah Daerah Tingkat I Bali lahir sebagai Daerah Otonom, sehingga pada tiap tanggal 14 Agustus di peringati sebagai Hari Lahirnya Provinsi Bali. Pada saat tersebut oleh Pemerintah Pusat telah ditunjuk Bapak I Gusti Bagus Oka sebagai pejabat sementara Kepala Daerah Tingkat I Bali untuk mengemban kebijakan dalam menumbuhkan harapan Aparatur Pemerintahan dan Masyarakat di Daerah Bali, memulai awal kegiatannya untuk menyelenggarakan Otonomi Daerahnya.

Dalam rangka penyelenggaraan urusan pemerintahan, Pemerintah Daerah menjalankan otonomi seluas-luasnya untuk mengatur dan mengurus sendiri urusan pemerintahaan berdasarkan otonomi dan tugas pembantuan. UndangUndang Nomor 64 Tahun 1958 Tentang Pembentukan Daerah-Daerah Tk.I Bali, Nusa Tenggara Barat dan Nusa Tenggara Timur (Lembaran Negara Republik Indonesia Tahun 2004 Nomor 53, Tambahan Lembaran Negara Republik Indonesia Nomor 4389) Peraturan Pemerintah Nomor 41 tahun 2007 Tentang Organisasi Perangkat Daerah mengamanatkan penetapan Susunan Organisasi dan 
Tata Kerja Perangkat Daerah dengan Peraturan Daerah. Berdasarkan landasan hukum diatas, diterbitkanlah Peraturan Daerah Provinsi Bali Nomor 4 Tahun 2013 tentang Perubahan atas Peraturan Daerah Provinsi Bali Nomor 4 Tahun 2011 tentang Organisasi dan Tata Kerja Perangkat Daerah Provinsi Bali dimana Biro Umum dan Protokol merupakan salah satu Organisasi Perangkat Daerah pada Sekretariat Daerah Provinsi Bali.

Tabel 2.

Hasil Uji Validitas

\begin{tabular}{cccc}
\hline Variabel & Indikator & Koefisien Korelasi & Keterangan \\
\hline Kepemimpinan & $\mathrm{X}_{1.1}$ & 0,831 & Valid \\
Transformasional $\left(\mathrm{X}_{1}\right)$ & $\mathrm{X}_{1.2}$ & 0,862 & Valid \\
& $\mathrm{X}_{1.3}$ & 0,805 & Valid \\
& $\mathrm{X}_{1.4}$ & 0,830 & Valid \\
Pemberdayaan Pegawai & $\mathrm{X}_{2.1}$ & 0520 & Valid \\
$\left(\mathrm{X}_{2}\right)$ & $\mathrm{X}_{2.2}$ & 0,719 & Valid \\
& $\mathrm{X}_{2.3}$ & 0,472 & Valid \\
& $\mathrm{X}_{2.4}$ & 0,642 & Valid \\
& $\mathrm{X}_{2.5}$ & 0,741 & Valid \\
Kepuasan Kerja & $\mathrm{X}_{2.6}$ & 0,526 & Valid \\
$(\mathrm{Y})$ & $\mathrm{Y}_{1}$ & 0,769 & Valid \\
& $\mathrm{Y}_{2}$ & 0,819 & Valid \\
& $\mathrm{Y}_{3}$ & 0,807 & Valid \\
& $\mathrm{Y}_{4}$ & 0,856 & Valid \\
& $\mathrm{Y}_{5}$ & 0,796 & Valid \\
& $\mathrm{Y}_{6}$ & 0,594 & Valid \\
\hline
\end{tabular}

Sumber : Data Diolah, 2017

Uji validitas instrumen dilakukan untuk mengukur keandalan dan ketepatan instrumen yang digunakan, instrumen yang valid merupakan instrumen yang benar-benar tepat untuk mengukur apa yang hendak diukur (Sugiyono, 2012:172). Instrumen dikatakan valid jika korelasi antara skor faktor dangan skor total bernilai positif dan nilainya lebih dari 0,30 ( $\mathrm{r}>0,30)$. Tabel 3.2 menyajikan hasil validitas instrument penelitian.

Hasil uji validitas pada Tabel 2 diatas menunjukkan bahwa seluruh variabel memiliki nilai koefisien korelasi dengan skor total seluruh item pernyataan lebih 
I Putu Sudibyadnyana, Pengaruh Kepemimpinan Transformasional dan...

besar dari 0,30. Hal ini menunjukkan bahwa butir-butir pernyataan dalam instrument penelitian tersebut valid

Suatu alat ukur dikatakan reliabel dapat dilihat melalui hasil Reliability Statistic dalam program SPSS. Variabel yang dikatakan reliabel apabila Koefisien Alpha Cronbach $=0,6$ artinya tingkat reliabilitas sebesar 0,6 meupakan indikasi reliabelnya sebuah konstruk (Ghozali, 2009:46). Suatu instrument dikatakan reliabel, jika instrument tersebut memiliki nilai Alpha Cronbach lebih dari 0,60. Adapun hasil dari uji reliabilitas dapat ditunjukkan pada Tabel 3 berikut.

Tabel 3.

Hasil Uji Reliabilitas

\begin{tabular}{clcc}
\hline No. & \multicolumn{1}{c}{ Variabel } & Cronbach's Alpha & Keterangan \\
\hline $\mathbf{1}$ & Kepemimpinan Transformasional $\left(\mathrm{X}_{1}\right)$ & 0,824 & Reliabel \\
$\mathbf{2}$ & Pemberdayaan Pegawai $\left(\mathrm{X}_{2}\right)$ & 0,742 & Reliabel \\
$\mathbf{3}$ & Kepuasan Kerja $(\mathrm{Y})$ & 0,793 & Reliabel \\
\hline \multicolumn{2}{l}{ Sumber: } & Data Diolah, 2017 &
\end{tabular}

Hasil uji reliabilitas yang disajikan dalam Tabel 3 menunjukkan bahwa seluruh instrumen penelitian memiliki koefisien Cronbach's Alpha lebih dari 0,60. Hal ini dapat dikatakan bahwa semua instrumen reliabel sehingga dapat digunakan untuk melakukan penelitian.

Pengujian data dalam penelitian ini menggunakan teknik analisis regresi linier berganda. Perhitungan koefisien regresi linier berganda dilakukan dengan analisis regresi melalui software SPSS 17.0 for Windows, diperoleh hasil yang ditunjukan pada Tabel 4 berikut. 
Tabel 4.

Hasil Analisis Regresi Linier Berganda

\begin{tabular}{|c|c|c|c|c|c|}
\hline \multirow[t]{2}{*}{ Model } & \multicolumn{2}{|c|}{$\begin{array}{l}\text { Unstandardized } \\
\text { Coefficients }\end{array}$} & \multirow{2}{*}{$\begin{array}{c}\begin{array}{c}\text { Standardize } \\
\text { d } \\
\text { Coefficients }\end{array} \\
\text { Beta } \\
\end{array}$} & \multirow[t]{2}{*}{$\mathbf{t}$} & \multirow[t]{2}{*}{ Sig. } \\
\hline & B & Std. Error & & & \\
\hline \multirow{4}{*}{$\begin{array}{ll}1 & \text { (Constant) } \\
& \text { Kepemimpinan } \\
& \text { Transformasional } \\
& \text { Pemberdayaan } \\
& \text { Pegawai } \\
\end{array}$} & 1.448 & 1.455 & & .995 & .323 \\
\hline & .577 & .107 & .409 & 5.401 & .000 \\
\hline & & & & & \\
\hline & .534 & .077 & .528 & 6.968 & .000 \\
\hline $\mathrm{R}$ & & & & & 0,855 \\
\hline R Square & & & & & 0,730 \\
\hline F Statistik & & & & & 112,334 \\
\hline Signifikansi & & & & & 0,000 \\
\hline
\end{tabular}

Berdasarkan hasil analisis regresi linier berganda seperti yang disajikan pada Tabel 4, maka persamaan strukturalnya adalah sebagai berikut.

$\mathrm{Y}=\mathrm{a}+\beta_{1} \mathrm{X}_{1}+\beta_{2} \mathrm{X}_{2}+\mathrm{e}$

$\mathrm{Y}=\mathrm{a}+0,409 \mathrm{X} 1+0,528 \mathrm{X} 2+\mathrm{e}$

Uji asumsi klasik dilakukan dengan tujuan untuk memastikan hasil yang diperoleh memenuhi asumsi dasar di dalam analisis regresi. Hasil uji asumsi klasik yang dilakukan dalam penelitian ini adalah uji normalitas, uji multikoliniearitas dan uji heteroskedastisitas. Hasil dari uji asumsi klasik yang diolah dengan bantuan software SPSS 17.0 disajikan sebagai berikut: nilai Kolmogorov Sminarnov (K-S) sebesar 0,702, sedangkan nilai Asymp. Sig. (2tailed) sebesar 0,707. Hasil tersebut mengindikasikan bahwa model persamaan regresi tersebut berdistribusi normal karena nilai Asymp. Sig. (2-tailed) 0,707 lebih besar dari nilai alpha 0,05. nilai tolerance dan VIF dari seluruh variable menunjukkan bahwa nilai tolerance untuk setiap variabel lebih besar dari $10 \%$ dan nilai VIF lebih kecil dari 10 yang berarti model persamaan regresi bebas dari 
I Putu Sudibyadnyana, Pengaruh Kepemimpinan Transformasional dan...

multikolinearitas. nilai Sig. dari variabel Kepemimpinan Transformasional, dan Pemberdayaan Pegawai, masing-masing sebesar 0,562 dan 0,180. Nilai tersebut lebih besar dari 0,05 yang berarti tidak terdapat pengaruh antara variabel bebas terhadap absolute residual. Dengan demikian, model yang dibuat tidak mengandung gejala heteroskedastisitas. Tabel 1 menunjukkan nilai determinasi total sebesar 0,730, mempunyai arti bahwa sebesar $73 \%$ variasi kepuasan kerja dipengaruhi oleh variasi kepemimpinan transformasional, dan pemberdayaan pegawai, sedangkan sisanya sebesar $27 \%$ djelaskan oleh faktor lain yang tidak dimasukkan ke dalam model. Berdasarkan hasil analisis pengaruh kepemimpinan transformasional terhadap kepuasan kerja pada Tabel 4.7 diperoleh nilai signifikansi sebesar 0,000 dengan nilai koefisien beta 0,409 . Nilai signifikansi $0,000<0,05$ mengindikasikan bahwa $\mathrm{H}_{0}$ ditolak dan $\mathrm{H}_{1}$ diterima. Hasil ini mempunyai arti bahwa kepemimpinan transformasional berpengaruh positif dan signifikan terhadap kepuasan kerja. Berdasarkan hasil analisis pengaruh pemberdayaan pegawai terhadap kepuasan kerja pada Tabel 4.7 diperoleh nilai signifikansi sebesar 0,000 dengan nilai koefisien beta 0,528. Nilai signifikansi $0,000<0,05$ mengindikasikan bahwa $\mathrm{H}_{0}$ ditolak dan $\mathrm{H}_{1}$ diterima. Hasil ini mempunyai arti bahwa pemberdayaan pegawai berpengaruh positif dan signifikan terhadap kepuasan kerja.

Kepemimpinan transformasional adalah kepemimpinan yang memotivasi karyawan untuk melakukan pekerjaan atau tugas lebih baik dari apa yang bawahan inginkan sehingga mampu menimbulkan kesadaran yang tinggi terhadap tujuan dan misi organisasi serta akan membangkitkan komitmen para pekerja 
untuk melihat dunia kerja melampaui batas-batas kepentingan pribadi demi kepentingan organisasi. Hasil pengujian penelitian ini menunjukan bahwa kepemimpinan tranformasional memiliki pengaruh positif dan signifikan terhadap kepuasan kerja. Artinya kepemimpinan transformasional yang tinggi akan meningkatkan kepuasan kerja pegawai. Memiliki arti bahwa penerapan kepemimpinan transformasional dapat memberikan kontribusi terhadap peningkatan kepuasan kerja pegawai Biro Umum dan Protokol Setda Provinsi Bali. Hasil penelitian sesuai dengan penelitian sebelumnya oleh Sonni (2013) yang mengatakan bahwa kepemimpinan transformasional, digambarkan sebagai gaya kepemimpinan yang dapat membangkitkan motivasi karyawan, sehingga dapat berkembang dan mencapai kinerja pada tingkat yang tinggi, melebihi dari apa yang mereka perkirakan sebelumnya. Penelitian yang dilakukan Yang (2012) juga memperoleh hasil bahwa kepemimpinan transformasional dapat memiliki dampak signifikan positif pada tingkat kepuasan kerja pegawai. Penelitian lain dari Suyuthi, dkk (2009) menunjukkan bahwa kepemimpinan transformasional memberikan tingkat pengaruh terhadap kepuasan kerja yang cukup kuat. Penelitian serupa oleh Omar and Fauzin Hussin (2013) juga mengatakan bahwa organisasi perlu memiliki pemimpin tipe transformasional untuk memberikan tim yang efektif dalam bekerja untuk meningkatkan kepuasan kerja.

Pemberdayaan pegawai merupakan upaya dari atasan terhadap bawahan untuk menjadikan pegawai lebih berdaya dengan cara memberikan wewenang dan kepercayaan dalam hal menjalankan pekerjaan maupun mengambil keputusan, sehingga akan menumbuhkan rasa tanggung jawab pada pegawai dalam 
I Putu Sudibyadnyana, Pengaruh Kepemimpinan Transformasional dan...

menjalankan pekerjaan. Hasil pengujian penelitian ini menemukan pengaruh positif dan signifikan pemberdayaan pegawai terhadap kepuasan kerja. Artinya pemberdayaan yang tinggi akan meningkatkan kepuasan kerja pegawai. Pemberdayaan yang tinggi cenderung meningkatkan kepuasan kerja pegawai Biro Umum dan Protokol Setda Provinsi Bali sehingga dapat membuat pegawai merasa memiliki kewajiban untuk berkontribusi dan peduli akan kesejahteraan organisasi serta membantu organisasi dalam pencapaian tujuannya.

Hasil penelitian ini didukung oleh penelitian yang dilakukan oleh Indradevi (2012) yang mengemukakan bahwa terdapat pengaruh positif antara pemberdayaan karyawan terhadap kepuasan kerja. Penelitian serupa yang dilakukan oleh Akbar et al. (2011), yang mengukur hubungan antara pemberdayaan karyawan dan kepuasan kerja di industri jasa Pakistan, menunjukkan hasil bahwa pemberdayaan karyawan berpengaruh signifikan terhadap kepuasan kerja. Penelitian yang dilakukan oleh Abadi (2013) menunjukkan bahwa pemberdayaan berpengaruh signifikan dengan kepuasan kerja. Mushipe (2011) juga menyatakan bahwa, terdapat hubungan positif antara pemberdayaan terhadap kepuasan kerja karyawan, semakin karyawan itu merasa diberdayakan maka tingkat kepuasan kerjanya meningkat dan begitu pula sebaliknya apabila karyawan kurang merasa diberdayakan maka kepuasan kerjanya akan menurun. Saeed (2013) pada penelitiannya yang menguji hubungan antara pemberdayaan karyawan dan kepuasan kerja juga menemukan hasil bahwa terdapat hubungan positif antara pemberdayaan karyawan terhadap kepuasan kerja. 


\section{KESIMPULAN DAN SARAN}

Berdasarkan tujuan penelitian, rumusan masalah dan hasil penelitian dengan pembahasan yang telah dipaparkan, maka dapat diambil kesimpulan dari penelitian sebagai berikut: kepemimpinan transformasional berpengaruh positif dan signifikan terhadap kepuasan kerja. Hal ini berarti bahwa kepemimpinan transformasional yang baik akan meningkatkan kepuasan kerja. Artinya, semakin baik kepemimpinan transformasional maka akan meningkatkan kepuasan kerja pada Biro Umum dan Protokol Setda Provinsi Bali. Pemberdayaan pegawai berpengaruh positif dan signifikan terhadap kepuasan kerja. Hal ini berarti bahwa semakin tinggi pemberdayaan pegawai maka semakin tinggi kepuasan kerja pada organisasi. Memiliki arti bahwa pemberdayaan pegawai yang tinggi cenderung membuat pegawai merasa memiliki rasa percaya diri dan peduli akan kesejahteraan organisasi serta membantu organisasi dalam pencapaian tujuannya, sehingga dapat meningkatkan kepuasan kerja.

Berdasarkan hasil penelitian dan kesimpulan, maka saran-saran yang dapat diberikan adalah agar kepemimpinan transformasional dapat terwujud dan kepuasan kerja dapat ditingkatkan, sebaiknya pimpinan membuat situasi dalam organisasi terasa senyaman mungkin agar pegawai merasa nyaman bekerja dan membuat pegawai merasa menjadi bagian keluarga organisasi tersebut. Rasa kekeluargaan yang tercipta akan membuat pegawai lebih baik dalam bekerja dan memberikan hasil yang bagus dalam bekerja.Untuk meningkatkan pemberdayaan pegawai, maka pihak instansi sebaiknya menciptakan hubungan kerja yang positif baik antara atasan dengan pegawai maupun antara sesama pegawai. Instansi 
I Putu Sudibyadnyana, Pengaruh Kepemimpinan Transformasional dan...

disarankan menyelenggarakan diklat pengembangan diri bagi para pegawai untuk meningkatkan kemampuan kerja.

\section{REFERENSI}

Abadi Mohammad Vali Nasar Ali., and Mehrdad Gaudarzvand Chegini. 2013. The Relationship Between Employees Empowerment With Job Satisfaction in Melli Bank of Guilan Province. Arabian Journal of Business and Manajemen Review, 2(12), 71-79.

Adeniji, Anthonia Adenike. 2011. Organizational Climate and Job Satisfaction Among Academic Staff in Some Selected Private Universities in Southwest Nigeria. Business Intelligence Journal, 4(1), 151-165.

Akbar, Syed Waqar., Muhamad, Yousuf, Naeeem Ui haq., and Ahmed, Imbran Hunjua. 2011. Impact of Employee Empowermen on Job Satisfaction An Eperical Analisys of Pakistani Service Industry. Interdisiplinary Journal Of Contemporary Research in Busines, 2(11), 680-685.

Astuti, E.S., Raharjo, K., and Hamid, D., 2013. The Effect Of Empowerment of The Organisasional Commitment And The Job Satisfacation of The Employees of The National Electricity Company (Ltd). Asian Transactions on Basic \& Applied Science, 3(4), 13-23.

Avram, Eugen., and Priescu, Iustin. 2012. Access to Information and Empowerment Perspectives in Health Services. Procedia Social and Behavioral Sciences, 33(1), 949-953.

Azzem, Hazem Kamal EI Din and Shaima, Salah Sayed. 2010. Influence of Empowering Employes on Job Satisfaction in Youth Care Administrations at Faculties of Assiut University A Comperative Study. World Journal of Sport Sciensces, 3(5), 1151-1159.

Bass, B.M., and B. J. Avolio. 2004. Multifactor Leadership Questionnaire (3rd ed.). California: Mindgarden, Redwood.

Bolden, R., Gosling, J., Marturano, A., and Denisson, P. 2003. A Review of Leadership Theory and Competency Frameworks. Centre for Leadership, 6(1), 1-44

Delf, R.L. 2009. Manajemen. Jakarta: Salemba Empat.

Dhermawan, A.A.N.B., Sudibya, I.G.A dan Utama, I.W.M. 2012. Pengaruh Motivasi, Lingkungan Kerja, Kompetensi, dan Kompetensi Terhadap 
Kepuasan Kerja dan Kinerja Karyawan. Jurnal Manajemen, Strategi Bisnis dan Kewirausahaan (Matrik), 6(2), 173-184

DuBrin, A. J. 2005. The Complate Ideal's Guide. Leadership. Edisi Kedua. Cetakan Pertama. Jakarta. Prenada.

Ellya, K.J. 2010, Pengembangan Karakter Intrapeaneur Melalui Model Kepemimpinan Transformasional. Jurnal Ilmiah Psikologi Industri dan Organisasi. 10(2), 346-349

Fernandez, Sergio., and Tima Moldogaziev. 2013. Employee Empowerment, Employee Attitudes, and Performance: Testing a ausal Model. Public Administration Review, 73(3), 490-506.

Ghozali, Imam. 2012. Aplikasi Analisis Multivariate Dengan Program IBM SPSS. Edisi Kelima. Semarang: Universitas Diponegoro.

Gibson, James L., Ivancevich, John M., Donnelly, James H. 1994. Organization Behavior, Structure, and Processes. $8^{\text {th }}$. Newyork. Irwin Inc.

Handoko, T. Hani. 2014. Manajemen Personalia dan Sumber Daya Manusia. Edisi Kedua. Yogyakarta. BPFE.

Hariandja, Marihot Tua Effendi. 2009. Manajemen Sumber Daya Manusia. Cetakan ke 5. Jakarta. PT. Grasindo.

Hasihabuan, SP. Melayu. 2014. Manajemen Sumber Daya Manusia. Edisi Revisi. Jakarta: Bumi Aksara.

Hughes, R. L., Ginnett, R. C and Curphy. G. J. 2012. Leadhership: Memperkaya Pelajaran dari Pengalaman. Edisi Ketujuh, Jakarta: Salemba Humanika.

Indradevi, R. 2012. The Impact of Psychological Empowerment on Job Performance and Job Satisfacation in India Software Compains. International Jurnal of Multidiciplinary Management Studies. 2(4), 34-48

Irsan, 2008. Pengaruh Kepemimpinan, Disain Pekerjaan, dan Iklim Organisasi Terhadap Kepuasan Kerja Tenaga Penunjang Akademik di Universitas Negeri Medan. Jurnal Manajemen Pendidikan, 4(1), 363-376.

Ismail, Azman., Hasan Al-Banna Mohamed., Ahmad Zaidi Sulaiman., Mohd Hamran Mohamad and Munirah Hanim Yusuf. 2011. An Empirical Study of the Relationship between Transformational Leadership, Empowermentand Organizational Commitment. Business and Economics Research Journal, 2(1), 89-107.

Kadarisma. 2012. Manajemen Pengembangan Sumber Daya Manusia. Edisi 1, cetakan pertama. Jakarta : Rajawali Pers. 
I Putu Sudibyadnyana, Pengaruh Kepemimpinan Transformasional dan...

Khuzaini, Thomas S. Kaihatu. 2008. Pentingnya Kepuasan Kerja Dalam Memidiasi Hubungan antara Pemberdayaan Anggota Terhadap Komitmen Organisasi. Majalah Ekonomi, 18(3), 312-324.

Kusmaningtyas, Amiartuti. 2013. Pengaruh Iklim Organisasi dan Kepemimpinan Terhadap Kepuasan Kerja Karyawan PT. Persada Jaya Indonesia di Kabupaten Sidoarjo. Jurnal Ekonomi dan Manajemen Bisnis. 4(1), 107120.

Lin, li-Fen., and Tseng, Cihun-chieh. 2013. The Influence of Leadership Behavior and Psychological Empowerment on Job Statisfaction. International Journal of Organizational Innovation. 5(4), 21-29

Maharani, Vivin., Eka, Afnan Troena dan Noermijati. 2013. Organizational Citizenship Behavior Role in Mediating the Effect of Transformational Leadership, Job Satisfaction on Employee Performance: Studies in PT Bank Syariah Mandiri Malang East Java. International Journal of Business and Management, 8(17), 1-12

Mathis, R.L dan Jackson. 2011. Human Resource Management. Jakarta: Salemba Empat.

Maulizar., dan Musnadi, Yunus. 2012. Pengaruh Kepemimpinan Transaksional dan Transformasional Terhadap Kinerja Karyawan Bank Syariah Mandiri Cabang Banda. Jurnal Ilmu Manajemen, 1(1), 1-13.

Northouse, Peter G. 2013. Kepemimpinan, Edisi Keenam, Jakarta Barat: Indeks.

Omar, W. W., and Hussin, F. 2013. Transformational leadership style and job satisfaction relationship. a study of Structural Equation Modeling (SEM). International Journal of Academic Research in Business \& Social Sciences, 3(2), 346-365.

Priyanto, D. 2014. SPSS Pengolah Data Terpraktis. Yogyakarta: ANDI.

Purnomo, Heru., dan Muhammad, Cholil. 2010. Pengaruh Gaya Kepemimpinan Terhadap Kepuasan Kerja Berdasarkan Motivasi Kerja Pada Karyawan Administratif di Universitas Sebelas Maret Surakarta. Jurnal Manajemen Sumber Daya Manusia, 4(1), 27-35.

Rivai, Veithzal., dan Sagala, Ella Jauvani. 2011. Manajemen Sumber Daya Manusia untuk Perusahaan dari Teori ke Praktik. Jakarta: PT Rajagrafindo Persada.

Saeed Amir., Abdul, Qayyum Chaudhry., Sahahbaz, Ahmad., and Ghalib ata. 2013. Measuring the Impact of Empowerment on Job Satisfaction Among 
the Middle Level Managers of Juc Descon Lahore. Social Behavior and Personality an international journal, 3(4), 89- 95.

Sahoo, Choudan Kumar., and Sitaram Das. 2011. Employee Empowerment A Strategy to Words Workplaye Commitment. Eropean Journal Of Business and Management, 3(11), 46-54.

Siagian, Sondang P. 2011. Manajemen Sumber Daya Manusia. Jakarta. Bumi Aksara.

Sonni, J. A. 2013. Pengaruh gaya kepemimpinan transformasional dan transaksional terhadap kinerja organisasi dengan budaya organisasi sebagai variabel pemoderasi (Studi empiris pada perusahaan perbankan Di Kota Padang). Jurnal Akuntansi, 1(1), 1-24

Sri, M. C., dan Elen, Puspitasari. 2014. Pengaruh Karakteristik Individu Terhadap Kinerja Auditor (Studi Empiris Auditor di Kantor Akuntan Publik (KAP) di Indonesia). Jurnal Ekonomi Bisnis, 1(1), 1370-1383.

Sugiyono. 2014. Metode Penelitian Bisnis (pendekatan kuantitatif, kualitatif dan $R \& D)$. Bandung : Alfabeta.

Sun, Li-Yun., Zhen, Zhang., Jin, Qi Zhen., and Xiong, Chen. 2012. Empoerment and Creativity: A Cross-Level Investigtion. The Leadership Quarterly, 23(1), 55-65

Sutrisno, H. Edy. 2014. Manajemen Sumber Daya Manusia. Jakarta. Kencana Prenada Media Group.

Suwatno, H dan Priansa, D.J. 2011. Manajemen SDM dalam Oranisasi Publik dan Bisnis. Bandung: Alfabeta.

Suyuthi, Nurmadhani Fitri., H. Djabir, Hamzah dan Otto R. Payangan. 2009. Pengaruh Gaya Kepemimpinan Transformasional dan Transaksional Terhadap Kinerja Melalui Kepuasan Kerja Karyawan PT. Telkom Divre VII Makassar, E-journal, 1(1), 1-7

Utama, Suyana. 2009. Aplikasi Analisis Kuantitatif. Denpasar: Fakultas Ekonomi Universitas Udayana.

Venkat R. Krishnan. 2005. Transformational leadership and outcomes: Role of relationship duration. Leadership and Organizational Journal, 26(5/6), 442-457.

Wibowo. 2011. Budaya Organisasi. Jakarta: Rajawali Pers.

2013. Manajemen Kinerja. Edisi Ketiga. Jakarta: PT Raja Grafindo Persada. 
I Putu Sudibyadnyana, Pengaruh Kepemimpinan Transformasional dan...

Wijono, Sunarto. 2012. Psikologi Industri Dan Organisasi Dalam Suatu Bidang Gerak Psikologi Sumber Daya Manusia. Edisi Revisi. Jakarta: Kencana Prenada Media Group.

Wuradji, 2008, The Educational Leadership (Kepemimpinan Trnasformasional), Gema Media, Yogyakarta.

Yang, M. L. 2012. Transformational leadership and Taiwanese public relations practitioners' job satisfaction and organizational commitment. Social Behavior and Personality an international journal, 40(1), 31-46

Yang, Seung-Bum., and Choi, Sang Ok. 2008. Employee Empowerment and Team Performance. Journal Emerald Group, 15(5/6), 289-301. 